\title{
Influence of different barley varieties on competition and yield performance in barley-oats mixtures at two levels of nitrogen fertilization
}

\author{
KARI JOKINEN \\ Kemira Oy, Espoo Research Centre, P.O. Box 44, \\ SF 02271 Espoo, Finland
}

\begin{abstract}
Competition between barley and oats, and yield performance of mixtures were evaluated in a two component replacement series field experiment at two levels of nitrogen applications ( $80 \mathrm{kgN} / \mathrm{ha}$ and $120 \mathrm{kgN} / \mathrm{ha}$ ). Three barley cultivars (Aapo, Agneta ja Ida) and one oats cultivar (Veli) were used.

The competitive relationship was independent of the pure stand yield of the cultivar. Ida and Agneta were more competitive than oats irrespective of nitrogen dose. Ida was the most dominant variety which was very likely due to the early development of the seedlings. Oats was slightly more competitive than the shortest cultivar Aapo at high nitrogen, although barley seedlings emerged before oats. Thus the competitive ability of a cultiyar was not determined by one character of the plant only.

The competition in mixtures had a greater effect on number of generative shoots and number of grains per head than on grain weight. The results revealed that the yield per plant in mixtures may be even the same as in monoculture, but the relative significance of different yield components may vary.

The grain and protein yield of mixtures did not differ significantly from the yield of the highest yielding component grown alone. However, the ratio of actual and expected yield and the relative yield total were in most cases higher than one, indicating that some yield advantage may have been achieved. The genotypic composition of the stand had the greatest influence on the grain protein content of oats.
\end{abstract}

Index words: Competition, yield, barley, oats, nitrogen fertilization, mixtures

\section{INTRODUCTION}

Competition among plant species has long been recognized as a major factor affecting crop production. Individual plants living within a mixed community will be exposed to com- petition from like and unlike individuals whenever and wherever the demand for an essential resource exceeds its immediate supply. Because each plant requires both above- and below-ground resources, its ability to grow in a habitat will be determined by the availabili- 
ties of these resources relative to the plant's morphological and physiological abilities to acquire these resources.

Beneficial competition between two crop species is often incorporated into cropping systems (VANDERMEer 1989). It is argued that the main benefits of growing mixtures, whether at the level of genus, species or variety, may include: higher yields, lower variability of yield from season to season, a better spread of production over the growth period, less susceptibility to disease or lodging and a superi-

\section{MATERIALS AND METHODS}

The replacement series field experiment was carried out in 1986 on the Kotkaniemi Experimental Farm of Kemira Oy in southern Finland $\left(60^{\circ} 22^{\prime} \mathrm{N}, 24^{\circ} 22^{\prime} \mathrm{E}\right)$ with barley and oats seeded separately $\left(500\right.$ seeds $\left./ \mathrm{m}^{2}\right)$ and in an equal mechanical mixture $(250 / 250)$. Three different barley cultivars (Aapo, Agneta and Ida) and one oats cultivar (Veli) were used. The general characters of the cultivars were (RANTANEN and SimOJOKI 1987):

\begin{tabular}{|c|c|c|c|c|c|}
\hline Variety & $\begin{array}{c}\text { Grain yield } \\
\text { kg/ha }\end{array}$ & $\begin{array}{c}\text { Growing } \\
\text { time } \\
\text { days }\end{array}$ & $\begin{array}{c}\text { Height } \\
\text { cm }\end{array}$ & $\begin{array}{c}1000- \\
\text { grain weight } \\
\mathrm{g}\end{array}$ & $\begin{array}{c}\text { Grain } \\
\text { protein } \\
\text { content } \%\end{array}$ \\
\hline Aapo (2-row) & 4740 & 97 & 62 & 37.3 & 11.8 \\
\hline Agneta (6-row) & 5100 & 87 & 81 & 37.2 & 12.0 \\
\hline Ida (2-row) & 4940 & 91 & 70 & 44.9 & 12.8 \\
\hline Veli & 4714 & 94 & 92 & 34.4 & 13.9 \\
\hline
\end{tabular}

or quality of the product (WoLFE 1985).

Many studies of barley-oats mixtures, as reviewed by JOKINEN (1991 a), indicate that yield increases over the mean of the components in monoculture have been observed. Some results from the field experiments even suggest that overyielding may occur. According to TRENBATH $(1974,1976)$, the mechanisms that might lead to the yield advantage of mixtures can be differing growth rhythms, differing rooting depths and nutritional complementation of the components. Also enhanced light and water use efficiency may be involved. Thus combining different kinds of genotypes it may be thought that one combination might more efficiently utilize the environment than the other.

The present study was initiated to investigate whether cultivars of spring barley differed in their relative performance in pure stands and in 50:50 mixtures with oats and, if so, to see if the differences could be related to competition effects on mixture components. The influence of nitrogen fertilization on competition and yield advantage was also evaluated.
A split-plot design (nitrogen levels in main plots and genotypic composition of stand in subplots) was used with four blocks. The soil was finer fine sand with $\mathrm{pH}$ 5.7. The plot size was $30 \mathrm{~m}^{2}(3 \mathrm{~m} \mathrm{x} \mathrm{10} \mathrm{m)} \mathrm{with} \mathrm{rows} \mathrm{spaced} 12.5$ $\mathrm{cm}$ apart. The granular fertilizer was NPK $(\mathrm{N}$ $16 \%, \mathrm{P} 7 \%, \mathrm{~K} 13 \%$ ) applied at the rate of 80 $\mathrm{kgN} / \mathrm{ha}$ and $120 \mathrm{kgN} / \mathrm{ha}$. The sowing date was 12 May. The crops were kept free of weeds by one application of the herbicide Actril S (2-3 liters/ha mixed with 300 liters of water) containing MCPA (235 g/l), dichlorprop (184 g/l), ioxynil (38 g/l) and bromoxynil $(24 \mathrm{~g} / \mathrm{l})$ at the time of shoot emergence.

The number of plants in each plot was determined by counting the number of seedlings in four randomly selected 1-m-long rows/plot about three weeks after sowing and before the initiation of tillering. The number of generative shoots was determined similarly after the complete ear emergence of all the cultivars. The emergence time of the seedlings as well as the height of the stands were evaluated visually.

At maturity the entire area of each plot was harvested (on 15 August) and the grain yields 
were determined $(\mathrm{kg} / \mathrm{ha}$ at $15 \%$ moisture content). From each mixture a $50 \mathrm{~g}$ sample was taken for determination of the seed yield of the barley and oats components. The separated samples of each mixture as well as samples of each pure stand yield were used for determination of the protein content $(\%)$ of the grain by the Kjeldahl method (500 mg with two subsamples) and 1000-grain weights (g) (3 x 100 seeds/sample). The number of grains/head was calculated using on data of yield, number of generative shoots and 1000 grain weight.

Relative yield (RY) and relative yield total (RYT) were calculated according to the methods of de WIT and van den BERG (1965). Relative protein yield and relative protein yield total were determined similarly. Competitive ratio (CR) was determined according to the method of WILEY and RAO (1980). The mean yield/area of four replications was calculated before computing the indices.

The grain yields, 1000 grain weight, number of generative shoots, the protein content of grain and protein yields were subjected to analyses of variance for split-plot design (Steel and Torrie 1980). Mean separation was accomplished by Tukey's honestly signifi- cant difference test (HSD) $(\mathrm{P}=0.05)$ (STEEL and Torrie 1980).

\section{RESULTS}

\section{The development of the stands}

All the barley varieties emerged a few days earlier than oats. The six-row barley Agneta and the two-row barley Aapo emerged more slowly than the two-row barley Ida. At the beginning of the growing season the density was approximately the same $(0.95-1.05)$ as expected (data not given). The height of the stands in descending order after the ear emergence was Veli, Agneta, Ida and Aapo.

\section{Grain yield}

In addition to the main effects there was also a significant interaction $(\mathrm{p}<0.05)$ between nitrogen fertilization and the genotypic composition of the stand. There were significant yield differences between the mixture yields only at low nitrogen, the mixture yield of Agneta and Veli being the smallest and the mixture yield of Aapo and Veli the greatest

Table 1. The grain yield ( $\mathrm{kg} / \mathrm{ha}$ ) of monocultures and mixtures of barley (Agneta, Ida and Aapo) and oats (Veli). $\mathrm{A} / \mathrm{E}$ is the ratio of the actual and expected yield of the mixtures. $\mathrm{CV}=$ Coefficient of variation of grain yields. Grain yield means in different nitrogen columns, grain yield means in the average column and grain yield means in the average row followed by the same letter are not significantly different at the 5\% level (HSD test).

\begin{tabular}{|c|c|c|c|c|c|c|c|}
\hline \multirow{3}{*}{ Stand } & \multicolumn{6}{|c|}{ Nitrogen fertilization $(\mathrm{kgN} / \mathrm{ha})$} & \multirow[t]{3}{*}{$\mathrm{CV}$} \\
\hline & \multicolumn{2}{|c|}{80} & \multicolumn{2}{|c|}{120} & \multicolumn{2}{|c|}{ Average } & \\
\hline & & $\mathrm{A} / \mathrm{E}$ & & $\mathrm{A} / \mathrm{E}$ & & $\mathrm{A} / \mathrm{E}$ & \\
\hline Veli (Ve) & $5149 \mathrm{~b}$ & & $5380 \mathrm{ab}$ & & $5265 \mathrm{~b}$ & & 7.1 \\
\hline Agneta(Ag) & 4711 a & & 5312 a & & 5012 a & & 8.3 \\
\hline Ida (Id) & $5054 \mathrm{ab}$ & & $5783 \mathrm{~cd}$ & & $5419 \mathrm{bc}$ & & 9.9 \\
\hline Aapo (Aa) & $5279 \mathrm{bc}$ & & $6058 \mathrm{~d}$ & & $5669 \mathrm{c}$ & & 12.1 \\
\hline $\mathrm{AgVe}$ & $4998 \mathrm{ab}$ & 101 & $5692 \mathrm{bc}$ & 106 & $5345 \mathrm{~b}$ & 104 & 9.1 \\
\hline IdVe & $5237 \mathrm{bc}$ & 103 & $5766 \mathrm{~cd}$ & 103 & 5502 bc & 103 & 7.9 \\
\hline $\mathrm{AaVe}$ & $5506 \mathrm{c}$ & 106 & 5715 bcd & 100 & $5611 \mathrm{c}$ & 103 & 8.8 \\
\hline Average & 5133 a & & $5672 \mathrm{~b}$ & & 5402 & & \\
\hline Mono & 5048 & 100 & 5633 & 100 & 5341 & 100 & \\
\hline 2-mixture & 5247 & 104 & 5724 & 102 & 5486 & 103 & \\
\hline
\end{tabular}


(Table 1). In contrast to barley varieties grown in monoculture Veli oats was rather insensitive to added nitrogen. At a low level of nitrogen fertilization Veli was as a good producer as the best barley variety Aapo. At a high level of nitrogen oats yielded the same as the lowest yielding barley variety, Agneta.

The yield of a given mixture was the same as or higher than the mean yield of the components grown in monoculture. The mixture yield was greater than the yield of the highest yielding component grown in monoculture in three cases out of six (Veli/Ida and Veli/Aapo at low nitrogen and Veli/Agneta at high nitro- gen). These differences varied from $2 \%$ to $6 \%$ and were not statistically significant $(\mathrm{p}>0.05)$.

\section{Relative yield, relative yield total and competitive ratio}

The results of relative yields of different barley varieties show that the Ida barley used the space in mixtures more efficiently than expected and more efficiently than the other barley varieties (Fig. 1). The relative yield of Agneta increased and Aapo decreased with increasing nitrogen fertilization. The relative yields of oats varied, mainly due to the bar-
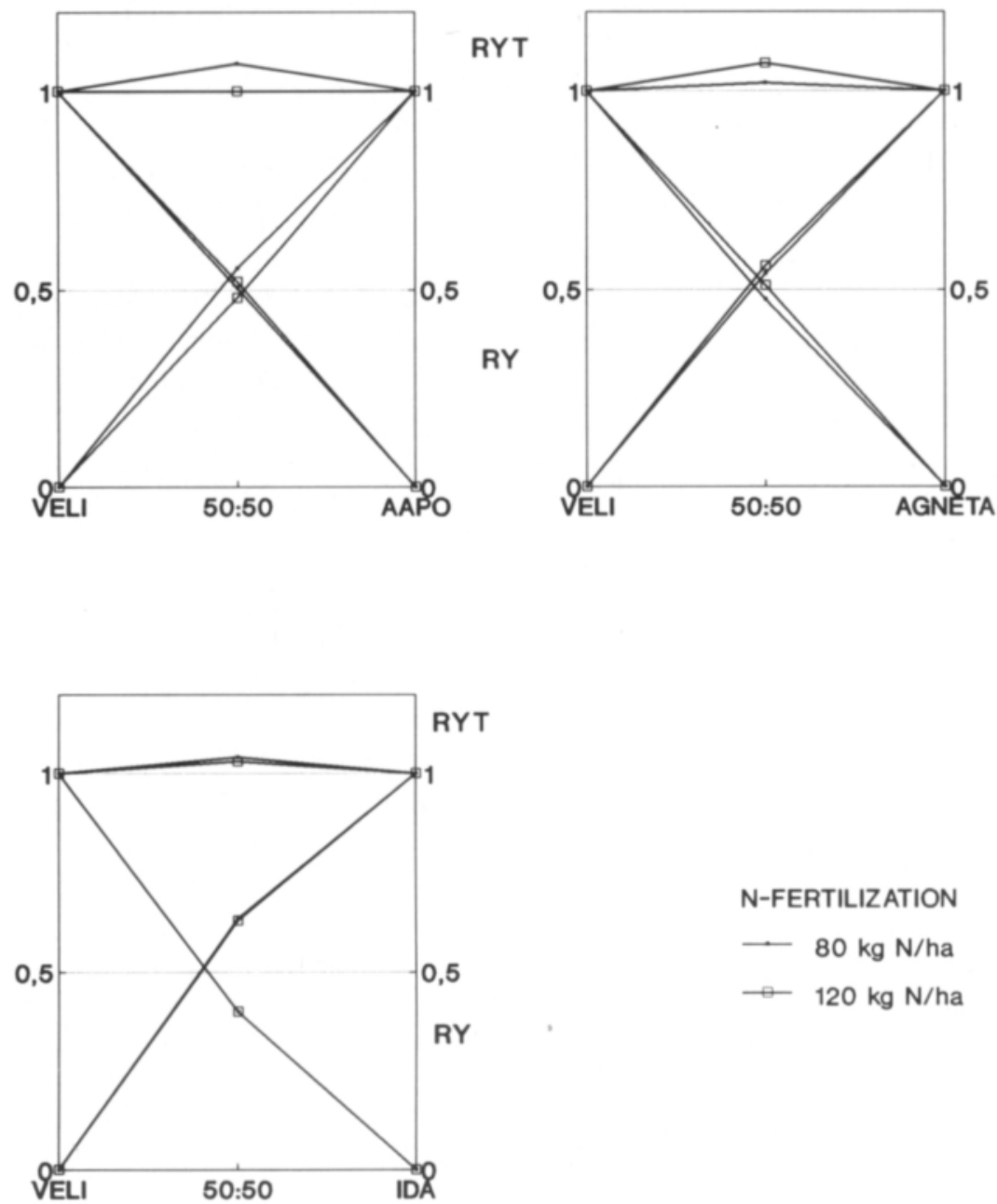

N-FERTILIZATION

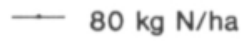

$\longrightarrow 120 \mathrm{~kg} \mathrm{~N} / \mathrm{ha}$

Figure 1. Relative yields (RY) of different cultivars of barley (Agneta, Ida and Aapo) and oats (Veli), and relative yield totals (RYT) of the mixtures at two levels of nitrogen fertilization. 
ley variety in the mixture being lowest in the mixture with Ida.

At low nitrogen level all the barley varieties were more competitive than oats, Ida being the most competitive barley variety (Table 2). An increase in nitrogen fertilization reversed only the competitive relationship between Aapo barley and Veli oats.

Both the barley variety and the level of nitrogen fertilization affected the relative yield total value which was equal to or greater than unity (Fig.1). The highest value was 1.07 both in the mixture of Agneta and Veli at the high

Table 2. The competitive ratio (CR) of barley to oats.

\begin{tabular}{lccc}
\hline & \multicolumn{3}{c}{ Nitrogen fertilization $(\mathrm{kgN} / \mathrm{ha})$} \\
\cline { 2 - 4 } Barley & 80 & 120 & Average \\
\hline Agneta & 1.13 & 1.10 & 1.12 \\
Ida & 1.58 & 1.58 & 1.58 \\
Aapo & 1.10 & 0.92 & 1.01 \\
\hline
\end{tabular}

Table 3. The influence of nitrogen fertilization and the genotypic composition of the stand on the number of generative shoots per plant of barley (Agneta, Ida and Aapo) and oats (Veli). Analysis of variance is done separately for each variety. Means in the average column and in the average row followed by the same letter are not significantly different at the $5 \%$ level (HSD test).

\begin{tabular}{lllll}
\hline & & \multicolumn{3}{c}{$\begin{array}{c}\text { Nitrogen fertilization } \\
\text { (kgN/ha) }\end{array}$} \\
\cline { 3 - 5 } Variety & Stand & 80 & 120 & Average \\
\hline Agneta(Ag) & Mono & 0.67 & 0.67 & $0.67 \mathrm{a}$ \\
& Mixture(Ve) & 0.72 & 0.67 & $0.70 \mathrm{a}$ \\
\hline \multirow{3}{*}{ Ida(Id) } & Average & $0.70 \mathrm{a}$ & $0.67 \mathrm{a}$ & 0.68 \\
& Mono & 1.04 & 1.04 & $1.04 \mathrm{a}$ \\
& Mixture(Ve) & 1.01 & 1.19 & $1.10 \mathrm{a}$ \\
\hline \multirow{3}{*}{ Aapo(Aa) } & Mverage & $1.04 \mathrm{a}$ & $1.12 \mathrm{a}$ & 1.07 \\
& Mixture(Ve) & 0.97 & 1.22 & $1.10 \mathrm{a}$ \\
\hline \multirow{3}{*}{ Veli(Ve) } & Average & $1.06 \mathrm{a}$ & $1.23 \mathrm{~b}$ & 1.15 \\
& Mono & 0.63 & 0.60 & $0.62 \mathrm{a}$ \\
& Mixture(Ag) & 0.85 & 0.79 & $0.82 \mathrm{~b}$ \\
& Mixture(Id) & 0.88 & 0.82 & $0.85 \mathrm{~b}$ \\
& Mixture(Aa) & 0.85 & 0.86 & $0.86 \mathrm{~b}$ \\
\hline & Average & $0.80 \mathrm{a}$ & $0.77 \mathrm{a}$ & 0.79 \\
\hline
\end{tabular}

level of nitrogen and in the mixture Aapo and Veli at the low level of nitrogen.

\section{Yield components}

In general the grain weight varied relatively less than the other yield components whether the components were grown in mixtures or in monocultures (Tables 3, 4, 5, and 6). The greater tillering of oats in all the mixtures compared with monoculture decreased the number of grains per head more than the grain weight. The amount of undercompensation was greatest in the mixture with Ida.

In mixtures where relative yield of a barley variety was higher than expected this was due not only to the higher relative number of grains per head but also in some cases to the higher relative shoot number. The considerably lower shoot number of Aapo in mixtures at low nitrogen was overcompensated by the grain number. The lower yield per plant of Aapo in mixtures than in monoculture at high

Table 4. The influence of nitrogen fertilization and the genotypic composition of the stand on the number of grains per head of barley (Agneta, Ida and Aapo) and oats (Veli).

\begin{tabular}{lllll}
\hline \multirow{2}{*}{ Variety } & & \multicolumn{3}{c}{$\begin{array}{c}\text { Nitrogen fertilization } \\
\text { (kgN/ha) }\end{array}$} \\
\cline { 3 - 5 } Agneta(Ag) & Stand & 80 & 120 & Average \\
& Mono & 33 & 37 & 35 \\
& Mixture(Ve) & 33 & 41 & 37 \\
\hline \multirow{4}{*}{ Ida(Id) } & Average & 33 & 39 & 36 \\
& Mono & 19 & 22 & 21 \\
& Mixture(Ve) & 25 & 24 & 25 \\
\hline \multirow{4}{*}{ Aapo(Aa) } & Average & 22 & 23 & 23 \\
& Mono & 20 & 21 & 21 \\
& Mixture(Ve) & 26 & 21 & 24 \\
\hline \multirow{4}{*}{ Veli(Ve) } & Average & 23 & 21 & 22 \\
& Mono & 47 & 51 & 49 \\
& Mixture(Ag) & 33 & 41 & 37 \\
& Mixture(Id) & 28 & 32 & 30 \\
& Mixture(Aa) & 37 & 39 & 38 \\
\hline & Average & 36 & 41 & 39 \\
\hline
\end{tabular}


Table 5. The influence of nitrogen fertilization and the genotypic composition of the stand on the thousand grain weight of barley (Agneta, Ida and Aapo) and oats (Veli). Analysis of variance is done separately for each variety. Means in the average column and in the average row followed by the same letter are not significantly different at the $5 \%$ level (HSD test).

\begin{tabular}{|c|c|c|c|c|}
\hline \multirow[b]{2}{*}{ Variety } & \multirow[b]{2}{*}{ Stand } & \multicolumn{3}{|c|}{$\begin{array}{l}\text { Nitrogen fertilization } \\
\qquad(\mathrm{kgN} / \mathrm{ha})\end{array}$} \\
\hline & & 80 & 120 & Average \\
\hline \multirow[t]{3}{*}{ Agneta(Ag) } & Mono & 38.3 & 38.6 & $38.5 \mathrm{a}$ \\
\hline & Mixture(Ve) & 37.7 & 38.8 & $38.2 \mathrm{a}$ \\
\hline & Average & $38.0 \mathrm{a}$ & $38.7 \mathrm{a}$ & 38.4 \\
\hline \multirow[t]{3}{*}{ Ida(Id) } & Mono & 47.2 & 46.5 & $46.8 \mathrm{a}$ \\
\hline & Mixture(Ve) & 46.5 & 46.3 & $46.4 \mathrm{a}$ \\
\hline & Average & 46.9 a & $46.4 \mathrm{a}$ & 46.6 \\
\hline \multirow[t]{3}{*}{ Aapo(Aa) } & Mono & 42.3 & 42.0 & $42.2 \mathrm{~b}$ \\
\hline & Mixture(Ve) & 41.1 & 40.7 & 40.9 a \\
\hline & Average & $41.7 \mathrm{a}$ & $41.4 \mathrm{a}$ & 41.5 \\
\hline \multirow[t]{5}{*}{ Veli(Ve) } & Mono & 31.3 & 31.9 & $31.6 \mathrm{a}$ \\
\hline & Mixture(Ag) & 31.0 & 31.2 & $31.1 \mathrm{a}$ \\
\hline & Mixture(Id) & 29.9 & 30.0 & $29.9 \mathrm{~b}$ \\
\hline & Mixture(Aa) & 29.6 & 30.3 & 29.9 b \\
\hline & Average & $30.5 \mathrm{a}$ & 30.9 a & 30.6 \\
\hline
\end{tabular}

nitrogen was mainly due to the lower grain weight.

\section{Grain protein content and protein yield}

The occurrence of oats in the stand had no
Table 7. The influence of nitrogen fertilization and the genotypic composition of the stand on grain protein content of barley (Agneta, Ida and Aapo) and oats (Veli). Analysis of variance is done separately for each variety. Means in the average column and in the average row followed by the same letter are not significantly different at the $5 \%$ level (HSD test).

\begin{tabular}{lllll}
\hline & & \multicolumn{3}{c}{$\begin{array}{c}\text { Nitrogen fertilization } \\
\text { (kgN/ha) }\end{array}$} \\
\cline { 3 - 5 } Variety & Stand & 80 & 120 & Average \\
\hline Agneta(Ag) & Mono & 11.1 & 12.3 & $11.7 \mathrm{a}$ \\
& Mixture(Ve) & 10.3 & 12.3 & $11.3 \mathrm{a}$ \\
\hline \multirow{3}{*}{ Ida(Id) } & Average & $10.7 \mathrm{a}$ & $12.3 \mathrm{a}$ & 11.5 \\
& Mono & 11.0 & 11.9 & $11.5 \mathrm{a}$ \\
& Mixture(Ve) & 10.6 & 11.9 & $11.3 \mathrm{a}$ \\
\hline \multirow{3}{*}{ Aapo(Aa) } & Mverage & $10.8 \mathrm{a}$ & $11.9 \mathrm{a}$ & 11.4 \\
& Mono & 10.5 & 11.4 & $11.0 \mathrm{a}$ \\
& Mixture(Ve) & 10.6 & 12.1 & $11.4 \mathrm{a}$ \\
\hline \multirow{3}{*}{ Veli(Ve) } & Average & $10.6 \mathrm{a}$ & $11.8 \mathrm{a}$ & 11.2 \\
& Mono & 11.8 & 13.1 & $12.5 \mathrm{a}$ \\
& Mixture(Ag) & 12.7 & 14.2 & $13.5 \mathrm{~b}$ \\
& Mixture(Id) & 11.7 & 13.6 & $12.7 \mathrm{ab}$ \\
& Mixture(Aa) & 11.6 & 13.4 & $12.5 \mathrm{a}$ \\
\hline & Average & $12.0 \mathrm{a}$ & $13.6 \mathrm{~b}$ & 12.8 \\
\hline
\end{tabular}

significant effect on the protein content of the barley varieties (Table 7). The protein content of oats was higher in the mixture with Agneta than in monoculture or in the other mixtures.

No overyielding in respect to protein yield

Table 6. Plant relative yields (PRY) and plant relative yield components of barley (Agneta, Ida and Aapo) and oats (Veli).*

\begin{tabular}{|c|c|c|c|c|c|c|c|c|}
\hline \multirow{3}{*}{ Variety } & \multicolumn{8}{|c|}{ Nitrogen fertilization $(\mathrm{kgN} / \mathrm{ha})$} \\
\hline & \multicolumn{4}{|c|}{$\begin{array}{c}80 \\
\text { Character }\end{array}$} & \multicolumn{4}{|c|}{$\begin{array}{c}120 \\
\text { Character }\end{array}$} \\
\hline & PRY & PRS & PRG & PRW & PRY & PRS & PRG & PRW \\
\hline $\operatorname{Agneta(Ag)}$ & 1.08 & 1.08 & 0.99 & 1.02 & 1.11 & 1.01 & 1.11 & 0.99 \\
\hline Ida(Id) & 1.27 & 0.99 & 1.32 & 0.99 & 1.26 & 1.14 & 1.12 & 0.98 \\
\hline $\operatorname{Aapo(Aa)}$ & 1.11 & 0.85 & 1.27 & 0.97 & 0.96 & 0.99 & 1.00 & 0.96 \\
\hline Veli(Ag) & 0.95 & 1.36 & 0.71 & 0.99 & 1.02 & 1.30 & 0.80 & 0.97 \\
\hline (Id) & 0.80 & 1.40 & 0.60 & 0.96 & 0.80 & 1.36 & 0.62 & 0.94 \\
\hline (Aa) & 1.01 & 1.35 & 0.78 & 0.95 & 1.04 & 1.43 & 0.76 & 0.95 \\
\hline
\end{tabular}

* $P R Y=$ Yield per plant in mixture/Yield per plant in monoculture.

PRS = Number of shoots per plant in mixture/Number of shoots per plant in monoculture.

$\mathrm{PRG}=$ Number of grains per head in mixture/Number of grains per head in monoculture.

$P R W=$ Grain weight in mixture/Grain weight in monoculture. 
Table 8. The protein yield ( $\mathrm{kg} / \mathrm{ha}$ ) of monocultures and mixtures of barley (Agneta, Ida and Aapo) and oats (Veli). $\mathrm{A} / \mathrm{E}$ is the ratio of the actual and expected yield of the mixtures. Yield means in the average column and yield means in the average row followed by the same letter are not significantly different at the $5 \%$ level (HSD test).

\begin{tabular}{|c|c|c|c|c|c|c|}
\hline \multirow{3}{*}{ Stand } & \multicolumn{6}{|c|}{ Nitrogen fertilization $(\mathrm{kgN} / \mathrm{ha})$} \\
\hline & \multirow[t]{2}{*}{80} & \multirow[b]{2}{*}{$\mathrm{A} / \mathrm{E}$} & \multirow[t]{2}{*}{120} & & \multirow[t]{2}{*}{ Average } & \multirow[b]{2}{*}{$\mathrm{A} / \mathrm{E}$} \\
\hline & & & & $\mathrm{A} / \mathrm{E}$ & & \\
\hline Veli (Ve) & 608 & & 704 & & $656 \mathrm{~b}$ & \\
\hline Agneta(Ag) & 522 & & 653 & & $588 \mathrm{a}$ & \\
\hline Ida (Id) & 556 & & 688 & & $622 a b$ & \\
\hline Aapo (Aa) & 554 & & 690 & & $622 \mathrm{ab}$ & \\
\hline $\mathrm{AgVe}$ & 573 & 101 & 752 & 110 & $663 \mathrm{~b}$ & 107 \\
\hline IdVe & 577 & 99 & 722 & 104 & $649 \mathrm{~b}$ & 102 \\
\hline $\mathrm{AaVe}$ & 609 & 105 & 730 & 105 & $670 \mathrm{~b}$ & 105 \\
\hline Average & 571 a & & $705 \mathrm{~b}$ & & 638 & \\
\hline Mono & 560 & 100 & 683 & 100 & 622 & 100 \\
\hline 2-mixture & 586 & 105 & 735 & 108 & 661 & 106 \\
\hline
\end{tabular}

of a mixture existed (Table 8). The protein yield of a mixture was usually higher than expected. The relative protein yield totals were in most cases above one (Table 9).

\section{DISCUSSION}

\section{Grain yield advantage}

The grain yield results of the present experiment suggest that mixtures of barley and oats

Table 9. The relative protein yields (RY) of barley (Agneta, Ida and Aapo) and oats (Veli) and the relative protein yield total of the mixtures (RYT) at two levels of nitrogen fertilization.

\begin{tabular}{|c|c|c|c|c|}
\hline \multirow[b]{3}{*}{ Mixture } & \multicolumn{4}{|c|}{ Nitrogen fertilization (kgN/ha) } \\
\hline & \multicolumn{2}{|c|}{80} & \multicolumn{2}{|c|}{120} \\
\hline & RY & RYT & RY & RYT \\
\hline Agneta & 0.50 & & 0.56 & \\
\hline \multirow[t]{2}{*}{ Veli } & 0.51 & & 0.55 & \\
\hline & & 1.01 & & 1.11 \\
\hline Ida & 0.61 & & 0.63 & \\
\hline \multirow[t]{2}{*}{ Veli } & 0.38 & & 0.41 & \\
\hline & & 0.99 & & 1.04 \\
\hline Aapo & 0.56 & & 0.48 & \\
\hline \multirow[t]{2}{*}{ Veli } & 0.49 & & 0.56 & \\
\hline & & 1.05 & & 1.04 \\
\hline Average & & 1.02 & & 1.06 \\
\hline
\end{tabular}

may yield more than the mean of the components grown alone and even overyield. However, the reader should observe that the grain yield of any mixture did not differ statistically significantly from the yield of the highest yielding component grown in monoculture. The results of other experiments in respect to overyielding of mixtures of barley and oats have been quite variable (for example SyME and Bremner 1968, Bebawi and Naylor 1978, TAYLOR 1978, Fejer et al. 1982 and JOKINEN $1991 \mathrm{a}, \mathrm{b})$.

The grain yield advantages of mixtures, especially when overyielding has occurred has not been statistically significant in most cases. This is partly because of the large variance usually associated with field experiments. Thus the failure to demonstrate an increase in the yield of a mixture need not necessarily mean the absence of a yield increase although it is in many cases rather small (i.e. below the limit of detection).

In two particular mixtures the relative yield total was 1.07 . This result suggests that these mixtures possibly exploited the resources more efficiently than both monocultures (TRENBATH 1978). The deviation of relative yield total from unity may also indicate that the density used in the experiment was not the optimum, as emphasized also by TRENBATH 
(1976), Connolly (1986) and Hảkansson (1988). Recently it was shown (JOKINEN 1991 c) that at rather low densities the relative yield total can be higher than at higher densities. The reader should observe that the yields of the small grains per area are not very sensitive to the change of density close to those used in commercial production (KIRKBY 1967, ERvió 1983). Because the objective of this study was first to identify possible beneficial crop combinations, a constant, near commercial density was used. However, in the next stage of the investigation, to evaluate the mixture advantage thoroughly, several densities and possibly proportions should be used.

The combination of Agneta barley and Veli oats may be worth further investigation in more variable environments. This is because by now in six experiments out of seven (including also some unpublished results) the relative yield total of the mixture has been higher than one at normal density and with normally used nitrogen fertilization ( $80-120$ $\mathrm{kgN} / \mathrm{ha}$ ). These results also suggest that there might be possibilities to identify specific combinations of barley and oats which could exploit the environmental resources more efficiently when grown in mixtures than in monocultures without increasing the costs of production.

\section{Competitive ability}

There were differences between the competitive abilities of the barley varieties. Two barleys, Ida and Agneta were always more competitive than oats. Ida was a superior competitor possibly because of its greatest seeds and its earliest emergence. According to SPITTERS (1984) differences in seedling size may be partly due to differences in seed weight.

Although all the barley varieties started their development earlier than oats, Aapo, the shortest variety, was a weaker competitor than oats at high level of nitrogen. This indicates that oats can be even more competitive than barley, agreeing with the results of de WIT
(1960), Syme and Bremner (1968) and JoKINEN (1991 a).

The reduced competitive ability of Agneta in the present experiment compared with earlier results at the same level of nitrogen fertilization (JOKINEN 1991 a, b) suggests that Agneta might suffer from the low $\mathrm{pH}$ of the soil as also discussed earlier (JOKINEN 1991 c). According to de WIT (1960), the competitive ability of barley may even decrease with decreasing $\mathrm{pH}$, although in monoculture the yield of barley is not significantly affected.

Although during vegetative growth it is question of biomass production, differences in biomass production will usually determine also the final yield. This is because harvest index is little affected by intergenotypic competition (SPITTERS 1979) and yield is the product of biomass and harvest index or the product of growth rate, growth duration and harvest index. Thus the final productivity of the plants like Aapo or Agneta in mixtures is not only determined by their initial growth but also by their ability to cope with the free space in the later stages of growth as shown by SPITTERS and KRAMER (1985).

As a rule the results of the present experiment suggests that the competitive ability or genotype predominance in a mixture is not necessarily related to a single character of a genotype like the initial status, plant height, tillering capacity or yielding ability, but is determined by the interaction of several plant traits.

\section{Yield formation and yield components}

The primary yield components of the small grain cereals develop sequentially in the order, panicles per plant, seeds per panicle, and weight per seed (BrINKMAN and FrEY 1977, Briggs 1978 p.273). However, in the present study only the yield component analysis leading to the final yield was performed only. Thus the collected data were too restricted for the thorough analysis of the yield formation occurring especially during the early part of the growing season. 
The reduced grain weight of Aapo grown in the mixture may indicate that oats shaded the shorter and later developing Aapo plants, decreasing the photosynthesis during grain filling. Shading has been shown to affect single grain weights (PeTERSON 1986). The reduced grain weight might be also due to the depletion of the limited supply of water and nutrients. Thus the earlier developing component like Ida in the mixture Veli or Veli in the mixture with Aapo might force the other component to ripen earlier. Subjecting the plant to nutrient and water stress during the critical period shortly after anthesis reduced the number of endosperm cells and mature dry weight commensurately (PeTERson 1986).

Attention needs to be paid to the result that in mixtures the relative importance of yield components may be different than in monoculture leading even to the same final yield per plant. Thus the plants did display phenotypic plasticity. The significance of different yield components to yield formation of oats and barley, whether grown in mixture or in monoculture have been rather variable in other experiments (for example SymE and BREMNER 1968, TAYLOR 1978, JOKINEN 1991 a). This shows that the yield formation is a complicated event in nature, especially if all three yield components are to be taken up for discussion in relation to each other and to several growth factors. In the present study, little information was available to interpret the effect of numerous factors and their interaction on dynamic a living system in which changes occurred from germination to maturity and on how resource availability might be modified by the competitors. Such information is really needed, as emphasized also by REEKIE and BAZZAZ (1989).

\section{Resource partitioning}

The results for the behaviour of Aapo and Veli indicate that the dominant-suppression relationship was not always complete. At low nitrogen, adjacent oat plants provided less in- terference than adjacent Aapo plants when grown alone and adjacent Aapo provided the same interference as adjacent oats plants when grown alone leading to the mixture advantage by overcompensation (RYT $>1$, RY $>0.5$ ). However, at high level nitrogen fertilization when there is usually an increased competition for the light (TILMAN 1982) the mutual competititon was so strong that the yield formation of Aapo was reduced and the dominantsuppression relationship was complete $(\mathrm{RYT}=1)$. Thus, fertilization with nitrogen led to a mixture stand which was dominated by the species which was superior competitors for non-nutrient resource light, agreeing with the results of JOKINEN (1991a). In natural plant communities there will be a decline in diversity (less coexistence) due to the enrichment of the community with nutrients (TILMAN 1982).

It is also important to note that in the present experiment the mutual competition was weak in the case of Agneta and Veli, especially at a high level of nitrogen fertilization instead of low nitrogen as reported recently (JOKINEN 1991 a). This may indicate the fact that the reduced competitive ability of Agneta in the present experiment (see section competitive ability above) reduced competition for the light.

As a conclusion the results suggest that the growing oat plants used the resource pool in different ways than the growing Aapo (or Agneta) plants at a certain point along the productivity gradient. This might indicate resource partitioning between components. Consequently, partitioning of light interception even under high productivity conditions may lead to weak mutual competition and yield advantage of a mixture. In the same sense as two species will coexist, two crop types will overyield if the mutual competition is sufficiently weak (VANDERMEER 1989).

\section{Protein content and protein yield}

The results of relative protein yield totals suggest that at high nitrogen some yield ad- 
vantage may be achieved by growing mixtures instead of monocultures, although significant overyielding did not occur. Benefits seem to relate closely to the amount of grain yields of the components whether grown in mixture or in monoculture.

The only significant differences in respect to protein content were found in the case of oats especially growing with Agneta barley. The increased protein content of oats grown in mixture is in agreement with earlier results from three experiments (JOKINEN unpubl.). This was always associated with lower grain yields of oats grown in mixtures than in monocultures, and thus no significant advantage of mixture in respect to protein yield was achieved. Also RAo and PRASAD (1987) found that the weaker competitor in a mixture had higher protein content than the stronger competitor but the losses and gains of the protein yields of the component cultivars were of equal magnitude. In general, the grain protein content in cereals is negatively correlated with grain yield (Welch and Yong 1980, Peterson 1986).

\section{References}

BeBawl, F.F. \& NaYLoR, R.E.L. 1978. Yield performance of mixtures of oats and barley. New Phytol. $81: 705-710$.

Briggs, D.E. 1978. Barley. 612 p. New York.

Brinkman, M.A. \& FreY, K.J. 1977. Yield-component analysis of oat isolines that produce different grain yields. Crop Sci.17:165-168.

Connolly, J.1986. On difficulties with replacementseries methodology in mixture experiments. J. Appl. Ecol. 23:125-137.

Ervıo, L-R. 1983. Competition between barley and annual weeds at different sowing densities. Ann. Agric. Fenn. 22:232-239.

Fejer, S.O., Fedak, G. \& Clark, R.V. 1982. Experiments with a barley-oat mixture and its components. Can. J. Pl. Sci. 62:497-500.

HäkAnSSON, S. 1988. Competition in stands of short-lived plants. Density effects measured in three-component stands. Swed. Univ. Agric. Sci. Dept. Crop Production Sci. Crop Production Sci. 3. 181 p. Uppsala.

JOKINEN, K. 1991 a. Competition and yield performance in mixtures of oats and barley - nitrogen fertilization, density and proportion of the components. J. Agric. Sci. Finl. 63:321-40.

JOKINEN, K. 1991 b. The effect of site on competition and yield advantage of mixture of barley and oats. J. Agric. Sci. Finl. 63:353-59.

JOKINEN, K. 1991 c. Assessment of competition and yield advantage in addition series of barley variety mixtures. J. Agric. Sci. Finl. 63:307-20.

KIRKBy, E.J.M. 1967. The effect of plant density upon the growth and yield of barley. J. Agric. Sci., Camb. $68: 317-24$.

Peterson, D.M. 1986. Some metabolic constraints to oat productivity. In Lawes,D.A. and Thomas,H.(eds.). Proceedings of the Second International Oats Con-

ference. p. 160-169. Martinus Nijhoff Publishers. Dordrecht.

Rantanen, O. \& Simojokı, P. 1987. Ohra. Peltokasvilajikkeet $1987-88$. Tieto tuottamaan $45: 28-35$. Helsinki.

RAO, B.R.R. \& PRASAD, R. 1987. Influence of competition, irrigation levels and nitrogen fertilization on protein content and protein yield of three spring wheat (Triticum aestivum L.) cultivars. Pl. Foods Human Nutr. 37:127-131.

Reekie, E.G. \& Bazzaz, F.A. 1989. Competition and patterns of resource use among seedlings of five tropical trees grown at ambient and elevated CO2. Oecologia $79: 212-222$.

SpItTER, C.J.T. 1979. Competition and its consequences for selection in barley breeding. Agric. Res. Rep. 893. 268 p. Wageningen.

SpItTERS, C.J.T. 1984. Effects of intergenotypic competition on selection. Proceed. 10th Congr. Eur. Assoc. Res. Pl. Breed. EUCARPIA. p.13-27. Wageningen.

Spitters, C.J.T. \& Kramer, TH. 1985. Changes in relative growth rate with plant ontogeny in spring wheat genotypes grown as isolated plants. Euphytica $34: 833-847$.

Steel, R.G.D. \& Torrie, J.H. 1980. Principles and procedures of statistics. A Biometrical Approach. 2nd Edition. 633 p. McGraw-Hill Kogakusha, Ltd. Tokyo.

Syme, J.R. \& BREMNER, B.M. 1968. Growth and yield of pure and mixed crops of oats and barley. J. Appl. Ecol. 5:659-674.

TAYLOR, B.R. 1978. Studies on a barley-oats mixture. J. Agric. Sci., Camb. 91:587-591.

TILman, D. 1982. Resource Competition and Community Structure. 296 p. Princeton University Press. Princeton.

TRENBATH, B.R. 1974. Biomass productivity of mixtures. 
Adv. Agron. 26:177-210.

Trenbath, B.R. 1976. Plant interactions in mixed crop communities. In: R.I. Papendick et al. (eds). Multiple Cropping. Am. Soc. Agron. Spec. Publ. 27:126-169. Madison.

Trenbath, B.R. 1978. Models and interpretation of mixture experiments. In Wilson, J.R. (ed.). Plant relations in pasture. CSIRO. p.145-162. Melbourne.

VANDERMeER, J. 1989. The Ecology of Intercropping. 237 p. Cambridge University Press. Cambridge.

WELCH, R.W. \& YONG, Y.Y. 1980. The effects of variety and nitrogen fertiliser on protein production in oats. J. Sci. Food Agric. 31:541-548.

WILLEY,R.W. \& RAO, M.R. 1980. A competitive ratio for quantifying competition between intercrops. Exp. Agric. 16:117-125.

WIT, C.T. de. 1960. On competition. Versl. Landbouwk. Onderz. 66.8:1-82.

WiT, C.T. de \& BERG, J.P. van den. 1965. Competition between herbage plants. Neth. J. Agric. Sci. 13:212-221.

WolfE, M.S. 1985. The current status and prospects of multiline cultivars and variety mixtures for disease resistance. Ann. Rev. Phytopath. 23:251-73.

\section{SELOSTUS}

\section{Eri ohralajikkeiden ja typpilannoituksen vaikutus kauran ja ohran väliseen kilpailuun ja seosten satoon.}

\section{Kari Jokinen}

Kemira Oy, Espoon tutkimuskeskus, PL 44, O227I Espoo

Kenttäkokeella selvitettiin, miten kolme ohralajiketta (Aapo, Agneta ja Ida) kilpailevat saman kauralajikkeen (Veli) kanssa kahden komponentin seoksessa, kun kasvuston typpilannoitus muuttuu koemallin ollessa korvaussarja. Kilpailun lisăksi tutkittin myös seoksesta saatavan satoedun mäăräă.

Lajikkeen kilpailukyky oli riippumaton lajikkeen puhdaskasvustosadon mäărăstả. Ohralajikkeiden kilpailukyky vaihteli Idan ja Agnetan ollessa dominoivampia kuin kaura riippumatta kasvuston typpilannoituksen määrästă ( 80 $\mathrm{kgN} / \mathrm{ha}$ tai $120 \mathrm{kgN} / \mathrm{ha}$ ). Ida oli kaikista lajikkeista dominoivin johtuen mită todennäköisimmin lajikkeen nopeimmasta alkukehityksestä. Kun seoskomponentti oli ohralajikkeista lyhin Aapo, typpilannoituksen lisäys muutti kilpailusuhteita kauran ollessa lievăsti dominoivampi kuin ohra.
Seoksessa tapahtuva kilpailu vaikutti suhteellisesti voimakkaammin versojen lukumääräăn ja tähkăn jyvälukuun kuin jyvänpainoon osoittaen, että kilpailusuhteet mäăräytyvät ja siten resurssien jakautuminen tapahtuu jo melko aikaisessa kehitysvaiheessa. Tulokset osoittivat, ettă lajikkeen yksilösato voi olla yhtä suuri seoksessa kuin puhdaskasvustossa, mutta eri satokomponenttien suhteellinen merkitys voi olla kuitenkin erilainen.

Seoksen jyvă- ja proteiinisato ei eronnut tilastollisesti merkitsevăsti seoksen komponenteista satoisimman komponentin puhdaskasvustosadosta. Seoksen toteutuneen ja odotetun sadon mäărăn vălinen suhde ja seoksen suhteellinen kokonaissato osoittivat, että joistakin seoksista voidaan saada lievăă satoetua. Kasvuston genotyyppinen koostumus vaikutti eniten kauran jyvăsadon valkuaispitoisuuteen. 